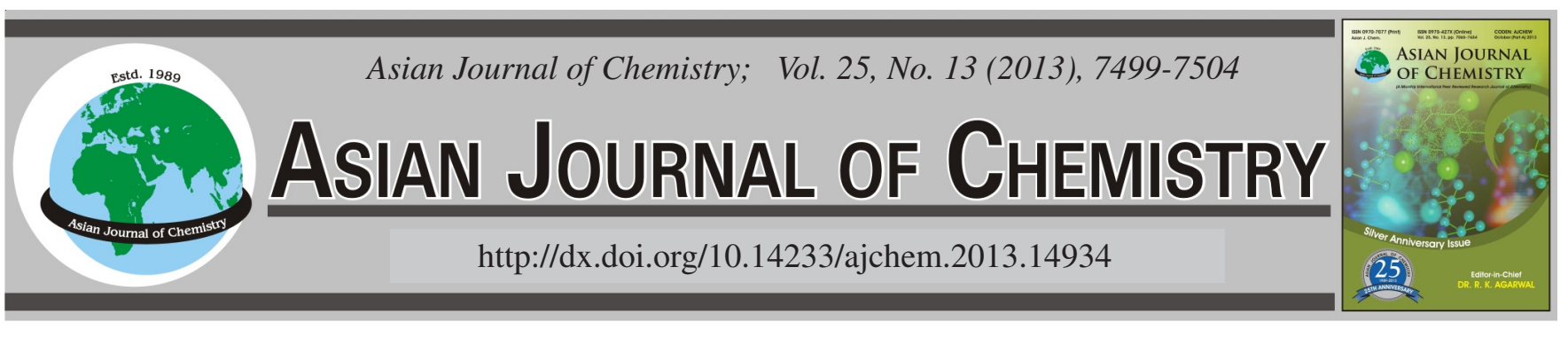

\title{
Synthesis and Characterization of Thiadiazolo[3,4-g]quinoxaline Based $\pi$-Conjugated Copolymers with Tunable Band Gaps
}

Feng TaO, Zheng Wang, Zuojia Li, Kai Li, Ying Li ${ }^{*}$ and Qiang Peng*

College of Chemistry, Sichuan University, Chengdu 610064, P.R. China

*Corresponding authors: Fax: +86 028 85413601; Tel: +86 028 85413601; E-mail: profliying@ sina.com; qiangpengjohnny@yahoo.com

\begin{abstract}
A series of alternating conjugated copolymers based on thiadiazolo[3,4-g]quinoxaline units and different electron-donating units, such as fluorene, benzene and thiophene, with donor (D)-acceptor (A) alternating structures have been synthesized by palladium catalyzed Sonogashira condensation polymerization. The resulting copolymers P1, P2 and P3 were characterized by NMR, IR, gel permeation chromatography, thermogravimetric analysis and differential scanning calorimetry. Their optical and electronic properties can be facilely fine-modulated by adjusting the structures of different aromatic or heteroaromatic blocks. UV-visible absorption and cyclic voltammetry measurements indicate that all these copolymers have low band gaps due to the strong interaction between the donor and thiadiazolo[3,4g]quinoxaline segments. Polymer P1 exhibits highest HOMO energy level, which can be expected to obtain high open-circuit voltage $\left(\mathrm{V}_{\mathrm{oc}}\right)$ from the fabricated PSCs. Polymer P3 based on thiophene and thiadiazolo[3,4-g]quinoxaline show smallest band gap and best absorption of sun light even in near-infrared (NIR) region. Preliminary studies imply that these copolymers can be used as efficient polymer donor materials in polymer solar cell applications.
\end{abstract}

Key Words: Thiadiazolo[3,4-g]quinoxaline, Low band gap, Optical absorbance, Electronic properties, Polymer solar cells.

\section{INTRODUCTION}

The development of efficient photovoltaic cells for renewable solar energy conversion is one of the most important ways to address the growing global energy needs. Polymer solar cells have attracted extensive research interest recently because of their potential advantages of low cost, light weight, flexibility, ease of processing and fabrication ${ }^{1-5}$. In the past decade, the regioregular poly(3-hexylthiophene) (P3HT) was extensively investigated as a polymer donor in typical bulkheterojunction solar cells ${ }^{6}$. However, the power conversion efficiencys of these devices using P3HT are limited at 4-5\%, because P3HT has a relatively large band gap and a highest occupied molecular orbital (HOMO) energy level ${ }^{7-10}$. After that, conjugated polymers featuring electron donor (D)-acceptor (A) units have been developed due to their tunable electronic properties, ambipolar charge transport abilities and enlarged spectral absorption ranges. Their band gaps and energy levels can be easily tuned by selecting appropriate electron-rich and electron-deficient blocks ${ }^{11-13}$. To achieve enhanced absorption and suitable energy levels, it is necessary to design and prepare low band gap copolymers with D-A structures ${ }^{14}$. Especially for multijunction polymer solar cells, it is still a challenge to develop low band gap copolymers for absorbing near-infrared (NIR) light ${ }^{15}$. As we know, the push-pull interaction can induce efficient photoinduced intramolecular charge transfer occurs from the donor to the acceptor units on photoexcitation, which lead to a lower energy absorption band ${ }^{16}$. The interesting intramolecular charge transfer structures in D-A copolymers can give rise to higher hole mobility ${ }^{17}$. In the past few years, power conversion efficiency values up to $9 \%$ were obtained in bulk-heterojunction solar cells by using low band gap copolymers as electron donors ${ }^{18-20}$.

The acceptor blocks that have been used for D-A low band gap alternating copolymers include 2,1,3-benzothiadiazole $(\mathrm{BT})^{21}$, thieno[3,4-b]pyrazine (TP $)^{22}$, quinoxaline $(\mathrm{QX})^{23}$ and pyrazino[2,3-g]quinoxaline $(\mathrm{PQX})^{24}$. Thiadiazolo[3,4-g]quinoxaline (TQX) is also an interesting electron-accepting skeleton with outstanding strong electron-withdrawing property of four imine groups ${ }^{25}$. A few D-A alternating copolymers containing TQX as the acceptor unit have been reported to have low band gaps of $0.90-1.50 \mathrm{eV}$, depending on the electron-donating ability of donor blocks and the bulkiness of side group of the acceptor unit $^{25-28}$. Although some research groups have synthesized TQX-based low band gap copolymers and reported the photovoltaic properties of those copolymers, the power conversion efficiencies were still below $1 \%^{25-28}$. So it is still necessary to design and prepare more TQX-based conjugated copolymers and study the relationship between their structures and properties. 
In this work, we synthesized three novel conjugated copolymers using TQX acceptor blocks through palladium catalyzed Sonogashira condensation polymerization. The fluorene, benzene and thipophene moieties were chosen as donor blocks because of their different electron-donating power. The long alkyl or alkoxyl side chains were attached onto the donor skeletons to enhance the solubility of the resulting copolymers for easy wet-processes of device fabrications (Scheme-I). The incorporation of triple-bond into the polymer backbones could be expected to isolate the large donor and acceptor blocks, avoiding the twisty and giving rise to the worse coplanarity of neighboring units compare to single- or double-bond.

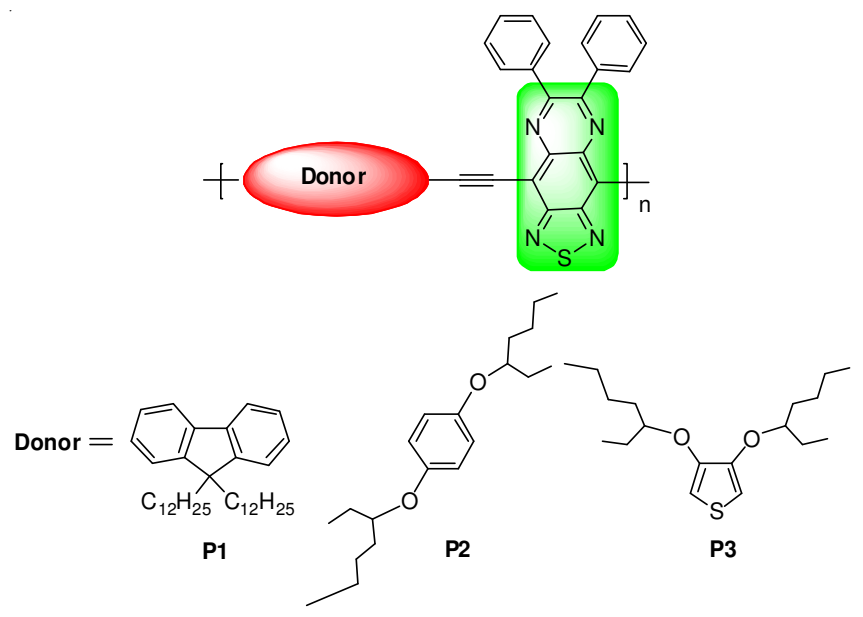

Scheme-I: Structures of the low band gap copolymers P1, P2 and P3

\section{EXPERIMENTAL}

All reagents were purchased from Aldrich or Acros Chemical companies and were used without further purification. All the solvents were purified according to the standard methods prior to use. 2,7-Dibromo-9,9-didodecyl-fluorene (1), ${ }^{29}$ 1,4-dibromo-2,5-bis(2-ethylhexyloxy)benzene ${ }^{30}$ and 3,4dimethoxythiophene ${ }^{31}$ were prepared according to the similar procedures reported before.

Characterizations: ${ }^{1} \mathrm{H}$ NMR spectra were recorded on a Bruker DRX 400 spectrometer with $\mathrm{CDCl}_{3}$ as the solvent and tetramethylsilane (TMS) as the internal standard. Numberaverage $\left(\mathrm{M}_{\mathrm{n}}\right)$, weight-average $\left(\mathrm{M}_{\mathrm{w}}\right)$ molecular weights and polydispersity indices $\left(\mathrm{M}_{\mathrm{w}} / \mathrm{M}_{\mathrm{n}}\right)$ of the copolymers were measured on a PL-GPC model 210 chromatograph at $25^{\circ} \mathrm{C}$, using THF as the eluent and standard polystyrene as the reference. TGA measurements were performed on a Perkin-Elmer series seven thermal analyzer at a heating rate of $20^{\circ} \mathrm{C} \mathrm{min}{ }^{-1}$ and under a nitrogen atmosphere. UV-visible spectra in solutions and thin films were taken on a Shimadzu UV 2100 UV-visible recording spectrophotometer. The cyclic voltammetry measurements were recorded on a computer-controlled EG \& G potential/galvanostat model 283 at room temperature.

\section{Synthesis of monomers}

9,9-Didodecyl-2,7-bis-(3-hydroxy-3-methyl-1-butynyl)fluorene (2): 2,7-Dibromo-9,9-didodecyl-fluorene 1 (2.0 g, $3.03 \mathrm{mmol})$, catalyst amount of $\mathrm{Pd}\left(\mathrm{PPh}_{3}\right)_{2} \mathrm{Cl}_{2}, \mathrm{CuI}$ and $\mathrm{PPh}_{3}$ were added to a three-neck round-bottom flask and the mixture was degassed with nitrogen three times. In addition, a mixture of $\mathrm{N}(\mathrm{Et})_{3} / \mathrm{THF}(25 \mathrm{~mL} / 25 \mathrm{~mL})$ was degassed at room temperature for $1 \mathrm{~h}$ and injected into the mixture and then 2-methyl-3-butyn-2-ol (1.79 g, $21.28 \mathrm{mmol})$ was injected. After complete addition, the reaction mixture was refluxed for $10 \mathrm{~h}$ and then cooled to room temperature. The resulting mixture was filtered, while the solvent was evaporated under reduced pressure. The product was purified by silica gel column chromatography with petroleum ether/ethyl acetate $(\mathrm{v} / \mathrm{v}, 8 / 1)$ as the eluent. After recrystallization from toluene, $1.97 \mathrm{~g}$ of 2 was obtained as a pale yellow solid $(42.8 \%) .{ }^{1} \mathrm{H}$ NMR (400 MHz, $\left.\mathrm{CDCl}_{3}\right): \delta 0.86-0.88(\mathrm{~m}, 6 \mathrm{H}), 1.01-1.27(\mathrm{~m}$, $40 \mathrm{H}), 1.66$ (s, 12H), 1.91-2.00 (m, 4H), 7.37-7.41 (m, 4H), 7.59-7.61 (m, 2H).

9,9-Didodecyl-2,7-diethynyl-9H-fluorene (3): Under an argon atmosphere, a solution of $2(1 \mathrm{~g}, 1.5 \mathrm{mmol})$ and $\mathrm{KOH}$ $(0.34 \mathrm{~g}, 6.0 \mathrm{mmol})$ in toluene $(15 \mathrm{~mL})$ was heated at $100{ }^{\circ} \mathrm{C}$ for $8 \mathrm{~h}$ and then the mixture was cooled to room temperature. After removal the solvent under reduced pressure, the pure product was purified by a silica gel column chromatography with petroleum ether as the eluent to give $0.46 \mathrm{~g}$ of $\mathbf{3}$ as a yellow solid (55.7\%). ${ }^{1} \mathrm{H} \mathrm{NMR}\left(400 \mathrm{MHz}, \mathrm{CDCl}_{3}\right)$ : $\delta 0.87-$ 0.89 (m, 6H), 1.03-1.28 (m, 40H), 1.92-1.95 (m, 4H), 3.15 (s, $2 \mathrm{H}), 7.46-7.49(\mathrm{~m}, 4 \mathrm{H}), 7.62-7.64(\mathrm{~m}, 2 \mathrm{H})$.

1,4-Bis-(3-hydroxy-3-methyl-1-butynyl)-2,5-bis(2ethylhexyloxy)-benzene (4): ${ }^{32}$ 1,4-Dibromo-2,5-bis-(2ethylhexyloxy)benzene $(2.62 \mathrm{~g}, 5.33 \mathrm{mmol})$ and catalytic amount of $\mathrm{Pd}\left(\mathrm{PPh}_{3}\right)_{2} \mathrm{Cl}_{2}, \mathrm{CuI}$ and $\mathrm{PPh}_{3}$ were added to a threeneck round-bottom flask, followed with three cycles of vacuum and argon. After degassing at room temperature for $1 \mathrm{~h}, \mathrm{~N}(\mathrm{Et})_{3} /$ THF $(20 \mathrm{~mL} / 30 \mathrm{~mL})$ was injected. Upon injecting 2-methyl3-butyn-2-ol (1.79 g, $21.3 \mathrm{mmol})$ to the flask, the reaction mixture was refluxed for $18 \mathrm{~h}$ and then cooled to room temperature. Subsequently, the mixture was separated by filtration and thw solvent was removed under reduced pressure to afford the crude product. The pure product was then purified by silica gel column chromatography with petroleum ether/ethyl acetate $(\mathrm{v} / \mathrm{v}, 8 / 1)$ as the eluent to afford $1.60 \mathrm{~g}$ of $\mathbf{4}$ as a light yellow solid (60.4\%). ${ }^{1} \mathrm{H}$ NMR (400 MHz, $\mathrm{CDCl}_{3}$ ): $\delta$ 0.90-0.97 (m, $12 \mathrm{H}), 1.31-1.47(\mathrm{~m}, 18 \mathrm{H}), 1.63(\mathrm{~s}, 12 \mathrm{H}), 1.80-2.05$ (broad, 2H), 3.81-3.86 (m, 4H), 6.87 (s, 2H).

1,4-Bis-(2-ethylhexyloxy)-2,5-diethynyl-benzene (5): ${ }^{32}$ Under an argon atmosphere, a solution of 4 (0.14 g, $0.28 \mathrm{mmol})$ and $\mathrm{KOH}(0.063 \mathrm{~g}, 1.12 \mathrm{mmol})$ in toluene $(10 \mathrm{~mL})$ was heated at $100{ }^{\circ} \mathrm{C}$ for $3 \mathrm{~h}$ and then cooled to room temperature. After removal the solvent under reduced pressure, the pure product was purified by silica gel column chromatography with petroleum ether/ $\mathrm{CH}_{2} \mathrm{Cl}_{2}(\mathrm{v} / \mathrm{v}, 8 / 1)$ as the eluent to give $0.054 \mathrm{~g}$ of $\mathbf{5}$ as a colourless viscous liquid (50.3\%). ${ }^{1} \mathrm{H}$ NMR (400 MHz, $\left.\mathrm{CDCl}_{3}\right): \delta$ 0.88-0.95 (m, 12H), 1.25-1.71 (m, 18H), $3.24(\mathrm{~s}$, 12H), 3.77 (dd, $4 \mathrm{H}, J=6.0 \mathrm{~Hz}), 6.88$ (s, 2H).

3,4-Bis-(2-ethylhexyloxy)-thiophene (6) ${ }^{33} 3,4$-Dimethoxythiophene (2.0 g,13.9 mmol), 2-ethylhexan-1-ol (7.7 g, 55.5 $\mathrm{mmol})$ and dry toluene $(50 \mathrm{~mL})$ were added to a three-neck round-bottom flask. The flask was equipped with a constant pressure funnel full with $\mathrm{CaCl}_{2}$ to absorb 2-ethylhexan-1-ol. The reaction solution was refluxed for $12 \mathrm{~h}$ and then cooled to room temperature. After removal the solvent under reduced pressure, the pure product was purified by a silica gel column 
chromatography with petroleum ether/ $\mathrm{CH}_{2} \mathrm{Cl}_{2}(\mathrm{v} / \mathrm{v}, 10 / 1)$ as the eluent to give $3.4 \mathrm{~g}$ of 6 as a light yellow vicous liquid $(72.4 \%) .{ }^{1} \mathrm{H}$ NMR $\left(400 \mathrm{MHz}, \mathrm{CDCl}_{3}\right): \delta 0.88-0.94(\mathrm{~m}, 12 \mathrm{H})$, $1.29-1.52(\mathrm{~m}, 18 \mathrm{H}), 1.71-1.79(\mathrm{~m}, 2 \mathrm{H}), 3.87(\mathrm{dd}, 4 \mathrm{H}, J=6.0$ $\mathrm{Hz}), 6.16$ (s, 2H).

2,5-Dibromo-3,4-bis-(2-ethylhexyloxy)-thiophene (7): $:^{34}$ Under an argon atmosphere, $N$-bromosuccinimide (NBS) $(4.12$ $\mathrm{g}, 23.16 \mathrm{mmol})$ was dissolved in dry DMF $(30 \mathrm{~mL})$. Then the mixture was added dropwise to a mixture of 3,4-bis-(2ethylhexyloxy)thiophene 6 (3.15 g, $9.26 \mathrm{mmol})$ in dry DMF $(100 \mathrm{~mL})$ in the dark. The reaction mixture was stirred at room temperature for $12 \mathrm{~h}$ and poured into water $(100 \mathrm{~mL})$. The organic material was extracted with ethyl ether three times. The combined organic extracts were washed with water and dried over anhydrous $\mathrm{MgSO}_{4}$. After removal the solvent under reduced pressure, the pure product was purified by a silica gel column chromatography with petroleum ether $/ \mathrm{CH}_{2} \mathrm{Cl}_{2}(\mathrm{v} / \mathrm{v}$, $12 / 1$ ) as the eluent to give $1.97 \mathrm{~g}$ of 7 as a colourless viscous liquid (42.8\%). ${ }^{1} \mathrm{H} \mathrm{NMR}\left(400 \mathrm{MHz}, \mathrm{CDCl}_{3}\right): \delta 0.91-0.95(\mathrm{~m}$, $12 \mathrm{H}), 1.29-1.52(\mathrm{~m}, 16 \mathrm{H}), 1.62-1.68(\mathrm{~m}, 2 \mathrm{H}), 3.93-3.95(\mathrm{~m}$, $4 \mathrm{H})$.

3,4-Bis-(2-ethylhexyloxy)-2,5-bis(3-hydroxy-3-methyl1-butynyl)-thiophene (8): 2,5-dibromo-3,4-bis-(2-ethylhexyloxy)thiophene 7 (2.65 g, $5.32 \mathrm{mmol})$, catalyst amount of $\mathrm{Pd}\left(\mathrm{PPh}_{3}\right)_{2} \mathrm{Cl}_{2}, \mathrm{CuI}$ and $\mathrm{PPh}_{3}$ were added to a three-neck round-bottom flask and the mixture was degassed with nitrogen three times. In addition, a mixture of $\mathrm{N}(\mathrm{Et})_{3}(25 \mathrm{~mL})$ and THF $(25 \mathrm{~mL})$ was degassed at room temperature for $1 \mathrm{~h}$ and injected into the mixture, followed by injecting $1.79 \mathrm{~g}$ (21.28 mmol) of 2-methyl-3-butyn-2-ol. The mixtures were refluxed for $12 \mathrm{~h}$ and then cooled to room temperature. After filtration and evaporation, the pure product was purified by a silica gel column chromatography with petroleum ether/ethyl acetate (v/v, 4/1) to give $0.82 \mathrm{~g}$ of $\mathbf{8}$ as a yellow vicous liquid $(30.5 \%) .{ }^{1} \mathrm{H}$ NMR $\left(400 \mathrm{MHz}, \mathrm{CDCl}_{3}\right): \delta 0.88-0.94(\mathrm{~m}, 12 \mathrm{H})$, $1.28-1.57(\mathrm{~m}, 16 \mathrm{H}), 1.58(\mathrm{~s}, 12 \mathrm{H}), 1.60-1.66(\mathrm{~m}, 2 \mathrm{H}), 4.11-$ $4.20(\mathrm{~m}, 4 \mathrm{H})$.

3,4-Bis-(2-ethylhexyloxy)-2,5-diethynylthiophene (9): Under an argon atmosphere, 3,4-bis-(2-ethylhexyloxy)-2,5bis-(3-hydroxy-3-methyl-1-butynyl) thiophene 8 (0.10 g, 1.98 $\mathrm{mmol})$ and $\mathrm{KOH}(0.044 \mathrm{~g}, 7.94 \mathrm{mmol})$ were dissolved in toluene $(10 \mathrm{~mL})$ and heated at $100{ }^{\circ} \mathrm{C}$ for $3 \mathrm{~h}$ and then cooled to room temperature. After removal the solvent under reduced pressure, the pure product was purified by a silica gel column chromatography with petroleum ether as the eluent to give $0.50 \mathrm{~g}$ of 9 as a yellow solid ( $65.1 \%) .{ }^{1} \mathrm{H}$ NMR (400 MHz, $\left.\mathrm{CDCl}_{3}\right): \delta 0.88-0.94(\mathrm{~m}, 12 \mathrm{H}), 1.26-1.56(\mathrm{~m}, 16 \mathrm{H}), 1.62-1.68$ (m, 2H), 3.39 (s, 2H), 4.17-4.24 (m, 4H).

Synthesis of polymers: Monomer (3, 5 or 9) $(0.10$ mmol), 4,9-dibromo-6,7-diphenyl-[1,2,5]thiadiazolo [3,4g]quinoxaline ( $0.10 \mathrm{mmol}), \mathrm{Pd}\left(\mathrm{PPh}_{3}\right)_{2} \mathrm{Cl}_{2}(0.00876 \mathrm{mmol}), \mathrm{CuI}$ $(0.00333 \mathrm{mmol})$ and $\mathrm{PPh}_{3}(0.048 \mathrm{mmol})$ were added to a 25 $\mathrm{mL}$ three-necked flask and the mixture was degassed with nitrogen three times. In addition, toluene $(6 \mathrm{~mL})$ and $2 \mathrm{~mol} / \mathrm{L}$ $\mathrm{K}_{2} \mathrm{CO}_{3}(3 \mathrm{~mL})$ were degassed at room temperature for $1 \mathrm{~h}$ and then injected into the mixture, respectively. The reaction was then stirred at $100{ }^{\circ} \mathrm{C}$ for $6 \mathrm{~h}$ and then cooled to room temperature. The reactant was poured into methanol $(250 \mathrm{~mL})$. After stirring for $30 \mathrm{~min}$, the precipitate was collected by filtration and washed repeatedly with water and then the crude product was Sohxlet extracted with acetone for $24 \mathrm{~h}$ to remove oligomers. The resulting copolymer was collected by filtration and dried under vacuum (Scheme-II).

\section{Spectral data}

P1: Dark blue solid. Yield: $82.5 \%$. IR ( $\mathrm{KBr}$ pellet, $\left.\mathrm{cm}^{-1}\right)$ : 3437, 2921, 2850, 2186, 1652, 1560, 1456, 1371, 1260, 1095, 1022, 897, 799, 760, 692. ${ }^{1} \mathrm{H} \mathrm{NMR}\left(400 \mathrm{MHz}, \mathrm{CDCl}_{3}, \delta / \mathrm{ppm}\right)$ : 0.84-0.88 (m, 6H), 1.16-1.68 (m, 40H), 1.86 (s, 4H), 6.99$7.88(\mathrm{~m}, 16 \mathrm{H})$.

P2: Dark blue solid. Yield: $80.6 \%$. IR ( $\mathrm{KBr}$ pellet, $\left.\mathrm{cm}^{-1}\right)$ : 3439, 2957, 2922, 2857, 2185, 1628, 1455, 1408, 1370, 1263, 1114, 1025, 899, 800, 762, 693. ${ }^{1} \mathrm{H}$ NMR (400 MHz, $\mathrm{CDCl}_{3}$,

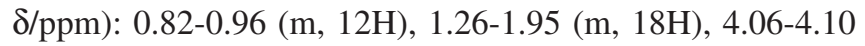
(m, 4H), 6.98 (s, 2H), 7.35-7.47 (m, 6H), $7.82(\mathrm{~m}, 4 \mathrm{H})$.

P3: Dark green solid. Yield: $75.9 \%$. IR ( $\mathrm{KBr}$ pellet, $\left.\mathrm{cm}^{-1}\right)$ : 3431, 2956, 2924, 2168, 1627, 1499, 1446, 1367, 1259, 1151, 1032, 802, 722, 693. ' $\mathrm{H}$ NMR (400 MHz, $\left.\mathrm{CDCl}_{3}, \delta / \mathrm{ppm}\right)$ : $0.86-0.88(\mathrm{~m}, 6 \mathrm{H}), 1.25-2.03(\mathrm{~m}, 18 \mathrm{H}), 3.72-3.74(\mathrm{~m}, 4 \mathrm{H})$, 7.44-7.49 (m, 4H), 7.53-7.55 (m, 2H), 7.65-7.69 (m, 4H).

\section{RESULTS AND DISCUSSION}

Synthesis and characterization: The chemical structures of the resulting copolymers was unambiguously confirmed by ${ }^{1} \mathrm{H}$ NMR and IR analysis. The prepared copolymers exhibit good solubility in common organic solvents, such as THF, $\mathrm{CHCl}_{3}, \mathrm{CH}_{2} \mathrm{Cl}_{2}$ and so on. Molecular weights of the copolymers are determined by GPC, using THF as the eluent and polystyrene as the standards. The GPC data show that weightaverage molecular weights $\left(\mathbf{M}_{\mathrm{w}}\right)$ of P1, P2 and $\mathbf{P 3}$ are 18000 $\mathrm{g} / \mathrm{mol}$ with polydispersity indice (PDI) of $1.9,7800 \mathrm{~g} / \mathrm{mol}$ with polydispersity indice of 1.4 and $11500 \mathrm{~g} / \mathrm{mol}$ with polydispersity indice of 1.9, respectively. Polymer $\mathbf{P 1}$ and $\mathbf{P 3}$ have relatively higher molecular weight than that of polymer $\mathbf{P 2}$ because of the steric hindrance induced by the 2-ethylhexyloxy side chains on phenyl ring (Table-1).

\begin{tabular}{cccccc}
\multicolumn{7}{c}{ TABLE-1 } \\
\multicolumn{7}{c}{$\begin{array}{c}\text { MOLECULAR WEIGHTS AND THERMAL } \\
\text { PROPERTIES OF THE COPOLYMERS }\end{array}$} \\
\hline Polymer & Yield $(\%)$ & $\mathrm{M}_{\mathrm{w}}{ }^{\mathrm{a}}$ & $\mathrm{PDI}\left(\mathrm{M}_{\mathrm{w}} / \mathrm{M}_{\mathrm{n}}\right)^{\mathrm{a}}$ & $\mathrm{T}_{\mathrm{d}}^{\mathrm{b}}\left({ }^{\circ} \mathrm{C}\right)$ & $\mathrm{T}_{\mathrm{g}}\left({ }^{\circ} \mathrm{C}\right)$ \\
\hline $\mathbf{P 1}$ & 82.5 & 18000 & 1.9 & 388 & 169 \\
$\mathbf{P 2}$ & 80.6 & 7800 & 1.4 & 362 & 165 \\
$\mathbf{P 3}$ & 75.9 & 11500 & 1.9 & 337 & - \\
\hline${ }^{\mathrm{a}}$ Molecular weights and PDI were measured by GPC \\
${ }^{\mathrm{b}} \mathrm{T}_{\mathrm{d}}$ is 5\% weight-loss temperatures under a nitrogen atmosphere
\end{tabular}

Thermal properties: Thermal stability of the copolymers was investigated with thermogravimetric analysis. As shown in Fig. 1a, The TGA curves reveal that the thermal decomposition temperature $\left(\mathrm{T}_{\mathrm{d}}, 95 \mathrm{wt} \%\right.$ residue) of $\mathbf{P 1}, \mathbf{P 2}$ and $\mathbf{P 3}$ are $388^{\circ} \mathrm{C}, 362{ }^{\circ} \mathrm{C}$ and $337^{\circ} \mathrm{C}$ in the inert nitrogen atmosphere, respectively. The results indicate that these polymers have good thermal stability, which are adequately suitable for avoiding the deformation and degradation of the polymeric active layer in polymer solar cells. The relatively higher thermal decomposition temperature of $\mathbf{P 1}$ than those of $\mathbf{P 2}$ and $\mathbf{P 3}$ is mostly 

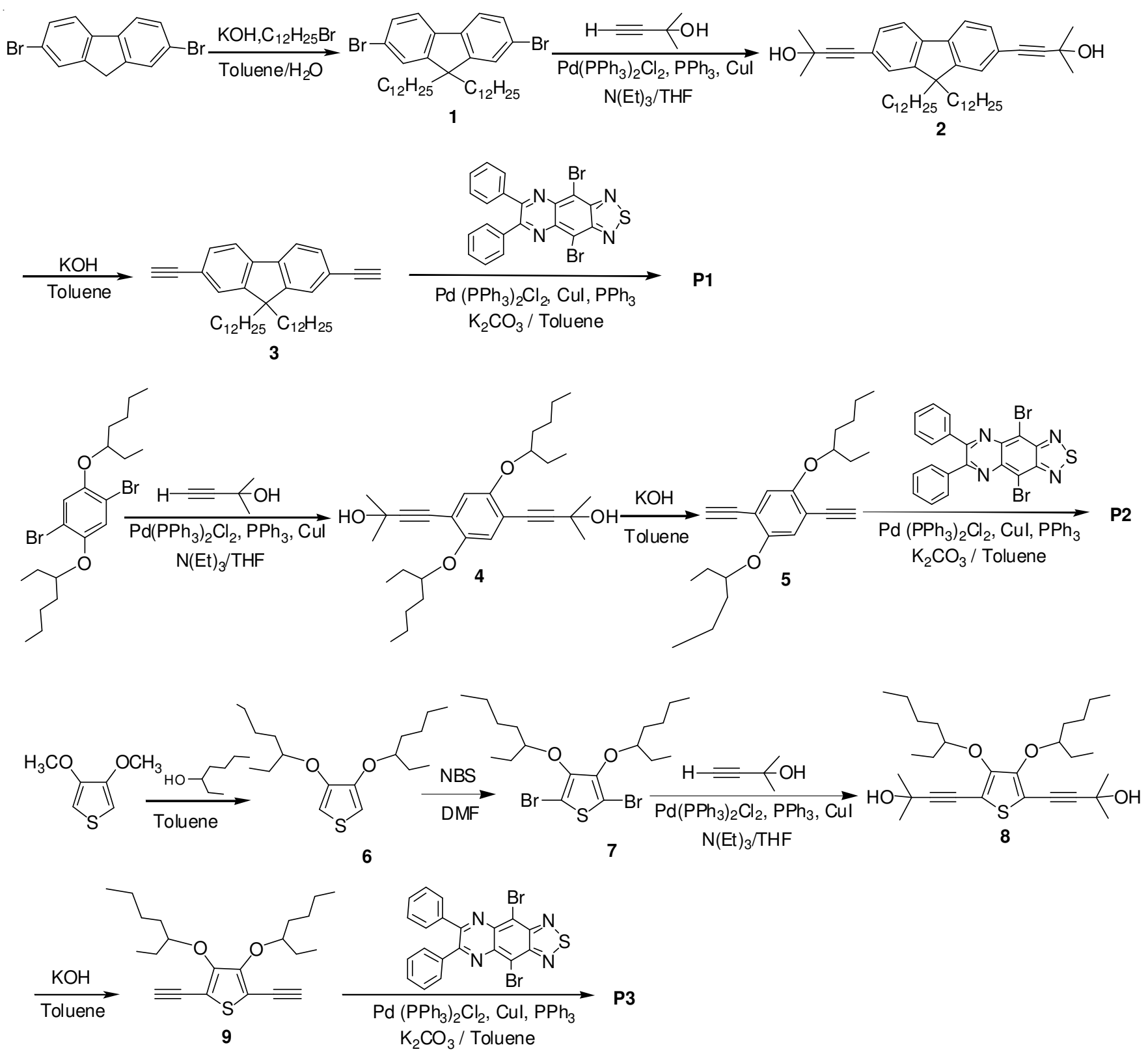

Scheme-II: Synthesis routes of the monomers and low band gap copolymers

because of the higher molecular weights and rigid properties of fluorene donor skeleton. The differential scanning calorimetry (DSC) curves of copolymers are shown in Fig. 1b. The DSC analysis reveals that both $\mathbf{P 1}$ and $\mathbf{P 2}$ have high glass transition temperatures $\left(\mathrm{T}_{\mathrm{g}}\right)$ of $169^{\circ} \mathrm{C}$ and $165^{\circ} \mathrm{C}$. However, the $\mathrm{T}_{\mathrm{g}}$ of $\mathbf{P 3}$ is not obviously observed.

Optical properties: UV-visible spectra were measured both in chloroform solutions and as thin films on quartz plates. The spectra are depicted in Fig. 2. The spectroscopic data of the copolymers are summarized in Table-2. As shown in Fig. 2a, the absorption peak maxima of the copolymer P1, P2 and $\mathbf{P 3}$ are 656, 667 and $714 \mathrm{~nm}$ in $\mathrm{CHCl}_{3}$ solution, respectively. The absorption peaks can be assigned to the $\pi-\pi^{*}$ transition of the delocalized structures resulted from the alternating D-A backbones in these copolymers. Obviously, the absorption spectra of P1 and P3 exhibited broader and stronger absorption than that of $\mathbf{P 2}$, which can be attributed to the stronger D-A interaction in the polymer backbones.

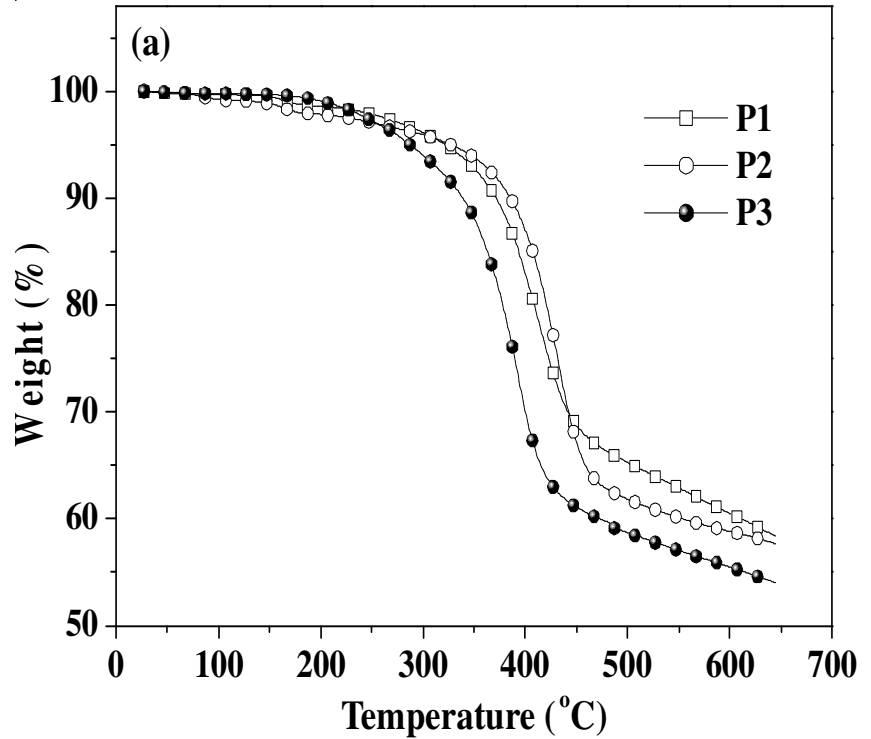




\begin{tabular}{|c|c|c|c|c|c|c|c|c|}
\hline \multicolumn{9}{|c|}{$\begin{array}{c}\text { TABLE-2 } \\
\text { OPTICAL AND ELECTROCHEMICAL DATA OF THE COPOLYMERS }\end{array}$} \\
\hline Polymer & $\begin{array}{c}\lambda_{\max , \text { sol }}^{\alpha} \\
(\mathrm{nm})\end{array}$ & $\begin{array}{c}\lambda_{\max , \text { film }} \\
(\mathrm{nm})\end{array}$ & $E^{b} g^{\text {opt }}(e V)$ & $E_{\text {onset, ox }}^{c}(V)$ & $\mathrm{E}_{\text {onset, red }}^{\mathrm{c}}(\mathrm{V})$ & HOMO $(\mathrm{eV})$ & LUMO ( eV) & $\mathrm{E}_{\mathrm{g}}^{\mathrm{ec}}(\mathrm{eV})$ \\
\hline P1 & 656 & 665 & 1.59 & 0.96 & -0.78 & -5.35 & -3.61 & 1.74 \\
\hline P2 & 667 & 693 & 1.45 & 0.87 & -0.79 & -5.26 & -3.60 & 1.66 \\
\hline P3 & 714 & 760 & 1.27 & 0.75 & -0.76 & -5.14 & -3.63 & 1.51 \\
\hline
\end{tabular}

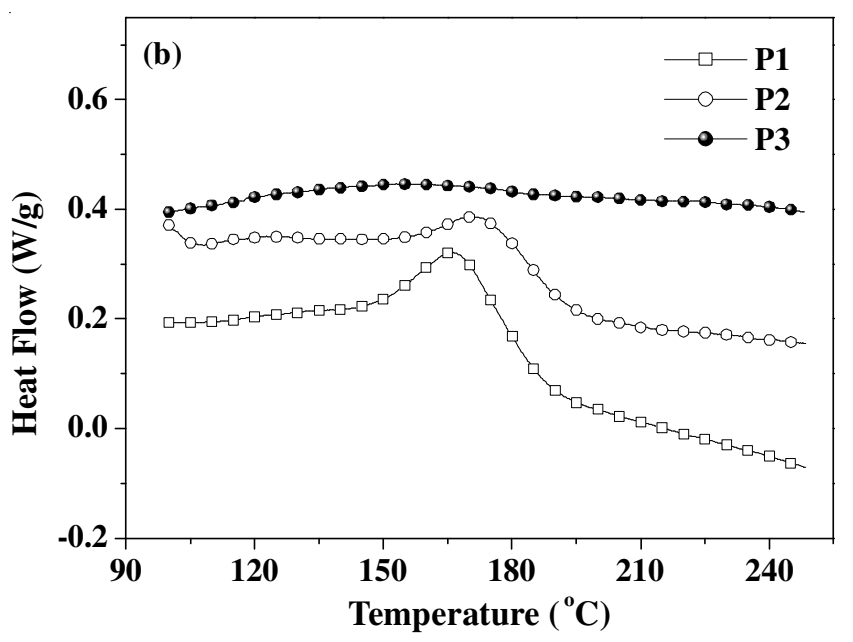

Fig. 1. (a) TGA and (b) DSC curves of the copolymers measured at a heating rate of $10{ }^{\circ} \mathrm{C} / \mathrm{min}$ under nitrogen
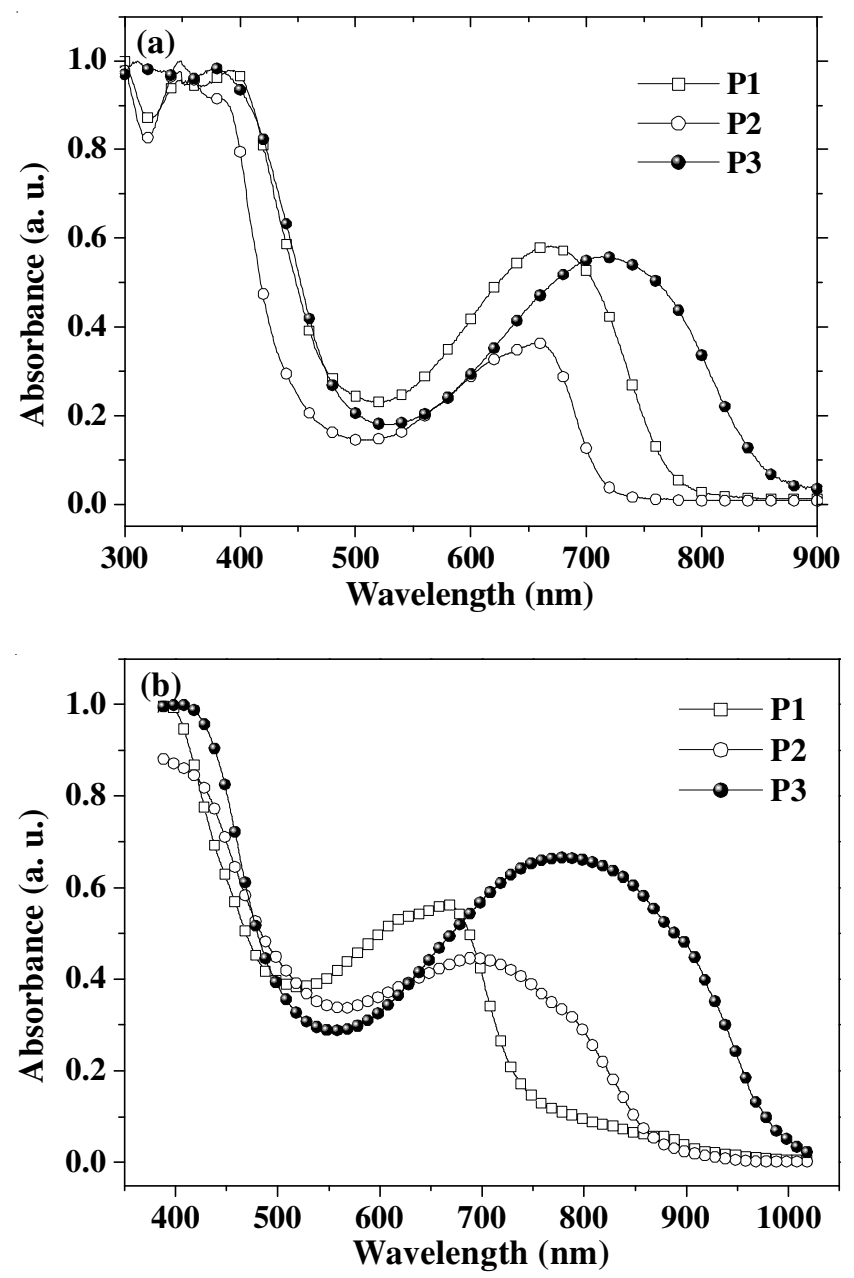

Fig. 2. UV-visible absorption spectra of the polymers solutions in $\mathrm{CHCl}_{3}$ solutions (a) and films on a quartz plate (b)
The thin solid films of the copolymers were obtained by spin-coating their chloroform solution. As shown in Fig. 2b, the absorption peak maxima of the copolymer P1, P2 and P3 are 665, 693 and $760 \mathrm{~nm}$ in films. The absorption maximum of P1, P2 and P3 thin films in visible region are red-shifted by 9, 26 and $47 \mathrm{~nm}$ in comparison with those from their solutions. The results indicate that there are strong intermolecular interaction and more aggregated configuration formed in solid state. ${ }^{9,35,36}$ Especially the polymer $\mathbf{P 3}$ exhibits a significantly enhanced absorption into the near-infrared region. The optical band gaps $\left(\mathrm{Eg}^{\mathrm{opt}}\right)$ are estimated to be $1.59,1.45$ and $1.27 \mathrm{eV}$ for $\mathbf{P 1}, \mathbf{P 2}$ and $\mathbf{P 3}$, respectively, from the band edge of the UV-visible absorption spectra of the copolymer films.

Electrochemical properties: The electrochemical redox behaviour of the copolymers was investigated by cyclic voltammetry. Cyclic voltammetry measurements were performed at a scan rate of $100 \mathrm{mV} \mathrm{s}^{-1}$ in a anhydrous acetonitrile solution with $0.1 \mathrm{~mol} \mathrm{~L}^{-1}$ tetrabutylammonium perchlorate $\left(n-\mathrm{Bu}_{4} \mathrm{NClO}_{4}\right)$ as the supported electrolyte at room temperature. The working electrode was a Pt disk, the counter electrode was a Pt wire and the reference electrode was a saturated calomel electrode. The cyclic curves of the copolymer thin films are shown in Fig. 3 and all the electrochemical data are summarized in Table-2. The onsets of oxidation potential ( $\left.E_{\text {onset, ox }}\right)$ of P1, P2 and P3 occurred at 0.96, 0.87 and $0.75 \mathrm{~V}$, respectively, while the corresponding onsets of reduction potential ( $\mathrm{E}_{\text {onset, red }}$ ) appeared at $-0.78 \mathrm{~V},-0.79 \mathrm{~V}$ and $-0.76 \mathrm{~V}$, respectively. $E_{\text {onset, ox }}$ and $E_{\text {onset, red }}$ are the onset potentials for oxidation and reduction potential relative to the SCE reference electrode, respectively. The HOMO and LUMO energy levels of polymers P1, P2 and P3 can be estimated by using the empirical equations: $\mathrm{I}_{\mathrm{p}}(\mathrm{HOMO})=-\left(\mathrm{E}_{\text {onset, ox }}+4.39\right) \mathrm{eV} ; \mathrm{E}_{\mathrm{a}}(\mathrm{LUMO})=$ $-\left(\mathrm{E}_{\text {onset, red }}+4.39\right) \mathrm{eV} ; \mathrm{E}_{\mathrm{g}}{ }^{\mathrm{ec}}=\mathrm{E}_{\text {onset, ox }}-\mathrm{E}_{\text {onset, red. }}{ }^{37}$ From these equations, the HOMO energy levels of P1, P2 and P3 were estimated to be $-5.35,-5.26 \mathrm{eV}$ and $-5.14 \mathrm{eV}$, respectively. On the other hand, the LUMO energy levels of P1, P2 and P3 were estimated to be $-3.61,-3.60$ and $-3.63 \mathrm{eV}$, respectively. The electrochemical band gaps $\left(\mathrm{E}_{\mathrm{g}}{ }^{\mathrm{ec}}\right)$ of the P1, P2 and P3 were calculated to be 1.74, 1.66 and $1.51 \mathrm{eV}$. Polymer $\mathbf{P 3}$ has the relative lower $\mathrm{E}_{\mathrm{g}}{ }^{\mathrm{ec}}$ among these three copolymers, which may be attributed to the stronger D-A interaction in the polymer backbone between thiophene ring and TQX unit. The lower band gap can afford improved absorbance even in NIR region. It is noted that polymer $\mathbf{P 1}$ exhibits high HOMO energy level, which can be expected to obtain high opencircuit voltage $\left(\mathrm{V}_{\mathrm{oc}}\right)$ from the fabricated polymer solar cells using $\mathbf{P 1}$ as a donor material. The electrochemical band gaps $\left(\mathrm{E}_{\mathrm{g}}{ }^{\mathrm{ec}}\right)$ values of these polymers are also agreed with above optical band gaps $\left(\mathrm{Eg}^{\mathrm{opt}}\right)$ values obtained from the UV-visible absorption. 


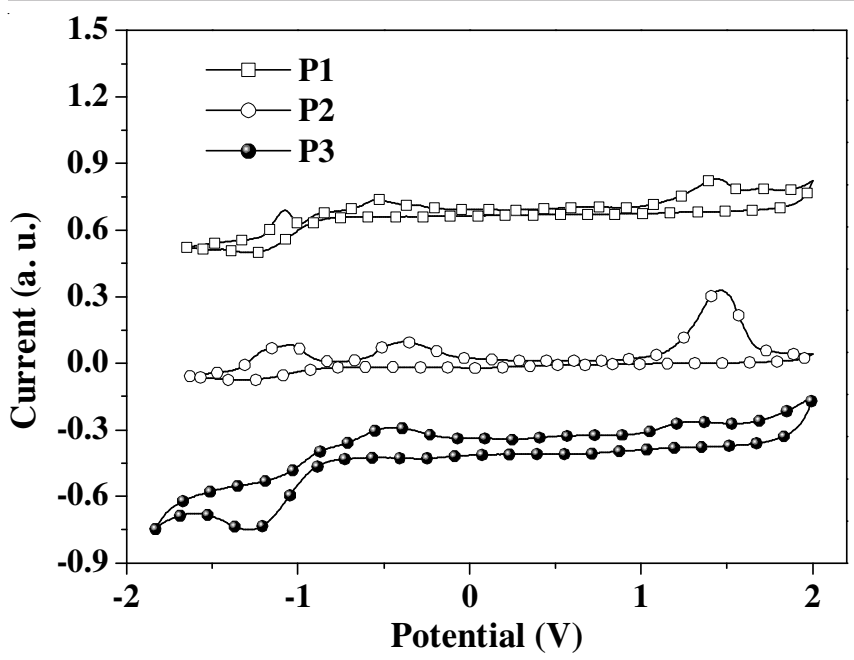

Fig. 3. Cyclic voltammograms of the copolymers at a scan rate of 100 $\mathrm{mV} / \mathrm{s}$ in a anhydrous acetonitrile solution with $0.1 \mathrm{M}$ tetrabutyl ammonium perchlorate

\section{Conclusion}

A series of donor (D)-acceptor (A) alternating copolymers, consisting of electron-deficient thiadiazolo[3,4-g]quinoxaline units and different electron-donating units, such as fluorene, benzene and thiophene, have been synthesized by palladium catalyzed Sonogashira condensation polymerization. Their optical and electrical properties can be facilely fine-modulated by adjusting the structures of different aromatic or heteroaromatic blocks. UV-visible absorption and cyclic voltammetry measurements show that all these copolymers have low band gaps due to the strong interaction between the donor and TQX segments. Polymer P1 exhibits deepest HOMO energy level, which can be expected to obtain high opencircuit voltage $\left(\mathrm{V}_{\mathrm{oc}}\right)$ from the fabricated polymer solar cells. Polymer P3 based on thiophene and TQX show smallest band gap and best absorption of sun light even in near-infrared region. Preliminary studies show that these copolymers are promising photovoltaic materials. Further experiments on photovoltaic properties, carrier transport mobility, film morphology and aggregation behaviours are in progress.

\section{ACKNOWLEDGEMENTS}

The work was financially supported by NSFC (No. 20802033, 21272164), Program for NCETU (No. NCET-100170), Key Foundation for Applied Basic Research Program of Sichuan Province (No. 2012JY0010), Scientific Research Foundation for Excellent Youth Scholars (No. 2012SCU04B01) and Recruit Talents of Sichuan University (No. YJ2011025).

\section{REFERENCES}

1. Y.F. Li and Y.P. Zou, Adv. Mater, 20, 2952 (2008).

2. Y.J. Cheng, S.H. Yang and C.H. Hsu, Chem. Rev., 109, 5868 (2009).

3. G.Y. Sang, Y.P. Zou and Y.F. Li, J. Phys. Chem. C, 112, 12058 (2008).

4. Q. Peng, X.J. Liu, D. Su, G.W. Fu, J. Xu and L.M. Dai, Adv. Mater, 23, 4554 (2011).

5. N. Tasios, C. Grigoriadis, M.R. Hansen, H. Wonneberger, C. Li, H.W. Spiess, K. Mullen and G. Floudas, J. Am. Chem. Soc., 132, 7478 (2010).
6. C.R.G. Grenier, S.J. George, T.J. Joncheray, E.W. Meijer and J.R. Reynolds, J. Am. Chem. Soc., 129, 10694 (2007).

7. W.L. Ma, C.Y. Yang, X. Gong, K. Lee and A.J. Heeger, Adv. Funct. Mater., 15, 1617 (2005).

8. G. Li, V. Shrotriya, J.S. Huang, Y. Yao, T. Moriarty, K. Emery and Y. Yang, Nat. Mater, 4, 864 (2005).

9. Q. Peng, K. Park, T. Lin, M. Durstock and L.M. Dai, J. Phys. Chem. B, 112, 2801 (2008)

10. Q. Peng, J. Xu and W.X. Zheng, J. Polym. Sci. Part A: Polym. Chem., 47, 3399 (2009).

11. L.J. Lindgren, F.L. Zhang, M. Andersson, S. Barrau, S. Hellström, W. Mammo, E. Perzon, O. Inganäs and M.R. Andersson, Chem. Mater., 21, 3491 (2009).

12. G. Dennler, M. Scharber, T. Ameri, P. Denk, K. Forberich, C. Wdaldauf and C.J. Brabec, Adv. Mater., 20, 579 (2008).

13. O. Thiebaut, H. Bock and E. Grelet, J. Am. Chem. Soc., 132, 6886 (2010).

14. A. Ajayaghosh, Chem. Soc. Rev., 32, 181 (2003).

15. E. Perzon, F. Zhang, M. Andersson, W. Mammo, O. Inganas and M.R. Andersson, Adv. Mater., 19, 3308 (2007).

16. A.J. Campbell, D.D.C. Bradley and H. Antoniadis, Appl. Phys. Lett., 79, 2133 (2001).

17. Q. Peng, Z.Y. Lu, Y. Huang, M.G. Xie, D. Xiao, S.H. Han, J.B. Peng and Y.J. Cao, J. Mater. Chem., 14, 396 (2004).

18. C.E. Small, S. Chen, J. Subbiah, C.M. Amb, S.W. Tsang, T.H. Lai, J.R. Reynolds and F. So, Nat. Photonics, 6, 115 (2012).

19. X.H. Li, W.C.H. Choy, L.J. Huo, F.X. Xie, W.E.I. Sha, B.F. Ding, X. Guo, Y.F. Li, J.H. Hou, J.B. You and Y. Yang, Adv. Mater, 24, 3046 (2012).

20. L.T. Dou, J.B. You, J. Yang, C.C. Chen, Y.J. He, S. Murase, T. Moriarty, K. Emery, G. Li and Y. Yang, Nat. Photonics, 6, 180 (2012).

21. M. Karikomi, C. Kitamura, S. Tanaka and Y. Yamashita, J. Am. Chem. Soc., 117, 6791 (1995)

22. Y. Zhu, C.T. Yen, S.A. Jenekhe and W.C. Chen, Macromol. Rapid Commun., 25, 1829 (2004).

23. Y. Zhu, R.D. Champion and S.A. Jenekhe, Macromolecules, 39, 8712 (2006).

24. M.H. Lai, C.C. Chueh, W.C. Chen, J.L. Wu and F.C. Chen, J. Polym. Sci. Part A: Polym. Chem., 47, 973 (2009).

25. M. Chen, E. Perzon, M.R. Andersson, S. Marcinkevicius, S.K.M. Jösson, M. Fahlman and M. Berggren, Appl. Phys. Lett., 84, 3570 (2004).

26. X. Wang, E. Perzon, F. Oswald, F. Langa, S. Admassie, M.R. Andersson and O. Inganäs, Adv. Funct. Mater, 15, 1665 (2005).

27. H. Yi, R.G. Johnson, A. Iraqi, D. Mohamad, R. Royce and D.G. Lidzey, Macromol. Rapid Commun., 29, 1804 (2008).

28. A.P. Zoombelt, M. Fonrodona, M.M. Wienk, A.B. Sieval, J.C. Hummelen and R.A.J. Janssen, Org. Lett., 11, 903 (2009).

29. N.C. Yang, S.M. Lee, Y.M. Yoo, J.K. Kim and D.H. Suh, J. Polym. Sci., Part A: Polym. Chem., 42, 1058 (2003).

30. D.A.M. Egbe, B. Cornelia, J. Nowotny, W. Gunther and E. Klemm, Macromolecules, 36, 5459 (2003).

31. S. Punidha, J. Sinha, A. Kumar and M. Ravikanth, J. Org. Chem., 73, 323 (2008).

32. Z. Zhao, S. Yu, L. Xu, H.B. Wang and P. Lu, Tetrahedron, 63, 7809 (2007).

33. Z. Zhao, X. Xu, H.Wang, P. Lu, G. Yu and Y.Q. Liu, J. Org. Chem., 73, 594 (2008).

34. L. Liu, W.Y. Wong, J.X. Shi, K.W. Cheah, T.H. Lee and L.M. Leung, J. Organomet. Chem., 691, 4028 (2006).

35. Q. Peng, S.L. Lim, I.H. Wong, J. Xu and Z.K. Chen, Chem. Eur. J., 18, 12140 (2012)

36. Q. Peng, Y.Y. Fu, X.J. Liu, J. Xu and Z.Y. Xie, Polym. Chem., 3, 2933 (2012).

37. Q. Peng, Z.Y. Lu, Y. Huang, M.G. Xie, S.H. Han and J.B. Peng and Y. Cao, Macromolecules, 37, 260 (2004). 